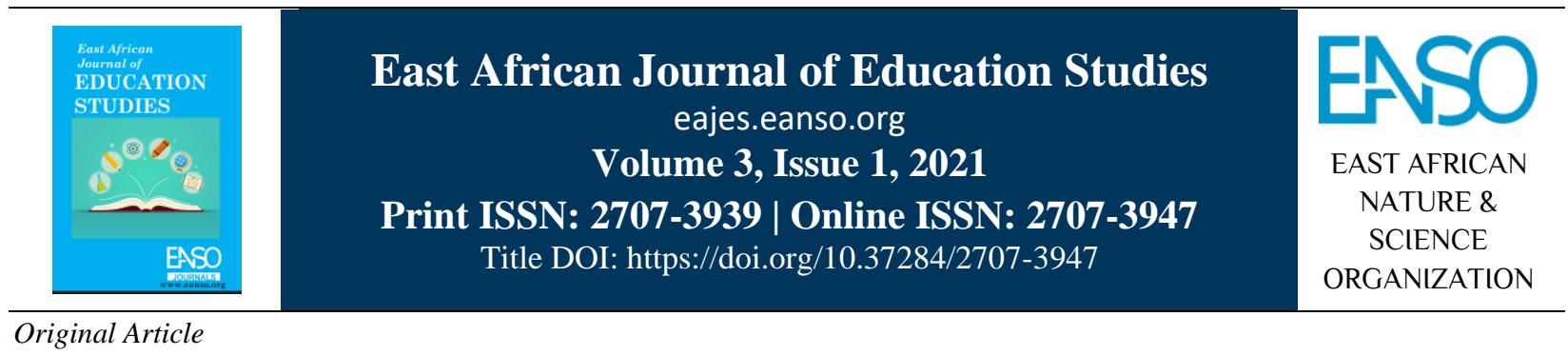

\title{
Decolonizing Religious Education to Enhance Sustainable Development in Africa: Evidence from Literature
}

\author{
Dr. Juliet Njeri Muasya, $P h D^{1}$ \\ ${ }^{1}$ School of Education, University of Nairobi, P. O. Box 30197 - 00100, Nairobi, Kenya. \\ *ORCID: https://orcid.org/0000-0002-4523-3305; Author for Correspondence Email: julietnjerim@gmail.com.
}

Article DOI: https://doi.org/10.37284/eajes.3.1.320

\section{Date Published: ABSTRACT}

16 April 2021 Decolonizing knowledge is the process of questioning, changing and transforming imposed theories and interpretations brought about by colonial

Keywords: $\quad$ systems. In particular, decolonizing Religious Education involves challenging religious systems and structures imposed by colonial masters. During the Decolonization, colonial period, religion was used as a tool of 'racism', 'apartheid' Religious Education,

Multi-Faith,

Peacebuilding, 'indoctrination', 'evangelisation' and 'exploitation', yet it is a subject that acknowledges and respects the diversity of African beliefs and culture. By decolonizing the Religious Education curriculum, the subject is likely to become a powerful tool for promoting sustainable development in Africa. In

Conflict Resolution, this paper, I argue that decolonized Religious Education is likely to contribute

Conservation, to development in Africa in a variety of ways; resolving conflict and

Moral Values, peacebuilding, management and conservation of natural resources, in addition to promoting appropriate religious beliefs and moral values. I conclude this

Cultural Tourism. paper by presenting a rationale for the inclusion of a multi-faith Religious Education curriculum in Kenya, while decolonizing Religious Education pedagogical approaches, in order to actualise Kenya's Vision 2030 and Big Four Agenda of the Jubilee Government

\section{APA CITATION}

Muasya, J. N. (2021). Decolonizing Religious Education to Enhance Sustainable Development in Africa: Evidence from Literature. East African Journal of Education Studies, 3(1), 77-86. https://doi.org/10.37284/eajes.3.1.320.

\section{CHICAGO CITATION}

Muasya, Juliet Njeri. 2021. "Decolonizing Religious Education to Enhance Sustainable Development in Africa: Evidence from Literature". East African Journal of Education Studies 3 (1), 77-86. https://doi.org/10.37284/eajes.3.1.320. 


\section{HARVARD CITATION}

Muasya, J. N. (2021) "Decolonizing Religious Education to Enhance Sustainable Development in Africa : Evidence from Literature", East African Journal of Education Studies, 3(1), pp. 77-86. doi: 10.37284/eajes.3.1.320.

\section{IEEE CITATION}

J. N. Muasya, "Decolonizing Religious Education to Enhance Sustainable Development in Africa: Evidence from Literature", EAJES, vol. 3, no. 1, pp. 77-86, Apr. 2021.

\section{MLA CITATION}

Muasya, Juliet Njeri. "Decolonizing Religious Education to Enhance Sustainable Development in Africa: Evidence from Literature". East African Journal of Education Studies, Vol. 3, no. 1, Apr. 2021, pp. 77-86, doi:10.37284/eajes.3.1.320.

\section{INTRODUCTION}

Generally, decolonising the curriculum involves changing what is taught and learnt by making African context and ideologies the centre from which the curriculum is grounded. Decolonizing curriculum does not necessitate the removal of 'western' knowledge but entails changing ways in which this knowledge dominates while excluding alternative knowledge in the curriculum (Unterhalter et al., 2019). Specifically, decolonizing Religious Education involves thinking and acting to ensure every student irrespective of their religious affiliations feels accepted within the education system (Ntombana \& Mokotso, 2018), including followers of African Traditional Religion. Religious Education has changed from being denominational within Christian traditions, to one that acknowledges and respects the diversity of other religions and beliefs in the society (Byrne, 2014). Thus, decolonizing Religious Education is about inclusion, recognition and affirmation, in terms of pedagogy and achievement (Ntombana \& Mokotso, 2018). Since decolonizing Religious Education is a developmental process, it requires sustainable commitment by different players. In this paper, the author will first conceptualise key terminologies; Religious Education and decolonizing Religious Education. Rationale of decolonizing Religious Education, ways in which decolonised Religious Education contributes to sustainable development in Africa and recommendations are discussed.

\section{Definition of Religious Education}

Religious Education is the act of teaching doctrines, beliefs, moral values and practices of various religions such as Christianity, Islam, Hindu, Buddhist, African Traditional Religion, Sikhism to mention but a few. The decolonization of Religious Education is meant to guide students on how to abide by the teachings, particularly moral principles and ethical standards of each religion, which makes them morally upright members of the society (Ozioma, 2017).

\section{Meaning of Decolonizing Religious Education}

Decolonization of knowledge is the process of ending any imposed knowledge, theories and interpretations, by questioning and transforming colonial knowledge systems and Eurocentrism (Savo, 2018). Decolonization process needs to challenge and critique dominant Western, Eurocentric discourses and misconceptions that see the African continent as characterised with backwardness, misery, starvation and savagery (Savo, 2018; Tshimpaka, 2018) and the African Religion as complicated, bizarre with primitive beliefs and practices (Alolo, 2007). Decolonization is not about neglect of knowledge, including the Eurocentric knowledge; rather it is about bringing Africa to the centre of everything (Savo, 2018), and in particular recognising the importance of African Traditional Religion in designing and facilitating African development (Awuah-Nyamekye, 2012). Decolonization of Religious Education is the ultimate call for freedom and African identity that reaffirms African values and beliefs (Katola, 2014; Msila 2017). Thus, to Ntombana \& Mokotso (2018) decolonizing Religious Education is about challenging and changing religious systems, structures and assumptions brought by colonisation.

Decolonized Religious Education becomes relevant, appropriate and meaningful to local, national and continental settings while functioning in the complex and interconnected world (Savo, 2018). Decolonized Religious Education has changed from being denominational within Christian traditions, to one that acknowledges and respects the diversity of other religions and beliefs 
in the society (Byrne, 2014). Thus, according to Ntombana \& Mokotso (2018) decolonizing Religious Education presents a way of thinking and acting that ensures every student irrespective of their religious affiliations including the adherents of African Traditional Religion feels accepted within an education system.

\section{Rationale of Decolonizing Religious Education}

Decolonizing Religious Education leads to the creation and construction of a new society based on its values, which then makes it challenging for scholars to ignore African religious values (Wa Thiong'o, 1981). Rodney (2012); Musitha \& Mafukata (2018) are of the view that decolonizing education, including Religious Education, is a catalyst for developing human capital which is likely to steer Africa towards economic, social and political development. This is supported by Amanze (2012) \& Tshimpaka (2018) who noted that a decolonized curriculum of theology and religious studies will help Africa respond and deal with the developmental needs, challenges and aspirations of its heterogeneous population based on human rights, economic and political justice. Specifically, Ogbonnaya (2012) \& Kagema (2015) are of the view that African traditions and culture can be used as a solution to conflicts, ethnic and inter-tribal tensions and wars, violence, hatred, poverty, environmental degradation, diseases, hunger, economic mismanagement and injustices that continue to prevail in the midst of colonial religious environment.

A decolonized Religious Education is a powerful tool for sustainable development since it promotes knowledge, attitudes and skill competencies desirable for social, economic and political development in Africa (Mafungulwa, 2014). It is no wonder Byrne (2014) \& Naaman (2015) noted as follows; to neglect Religious Education, especially African Traditional Religion is to neglect the future development of Africa, since it acts as a reliable agent or institution that provides a stepping stone to sustainable development. Naaman (2015) stipulates that as long as secular discourses continue to exclude African Traditional Religion in its analysis of globalization, progress and development, the results of its analysis will always be defective. Thus, neglecting 'primal' religions which is the source of normative meaning and superstructural institutions of society is underestimating development in Africa (Awuah-Nyamekye, 2012; Naaman, 2015).

According to Kagema (2015), the religiosity of Africans helps create an atmosphere where justice, reconciliation and peace prevail at all times. As a unique religion, inscribed in the hearts of Africans, African Traditional Religion continue to address the spiritual needs and realities of Africans (Kagema, 2015). As an integral part of life, African Traditional Religion shapes social, political organisation, economic activities, practices, culture and growth of other religions (Alolo, 2007; Kagema, 2015). According to Alolo (2007), any sustainable development can to some extent be enhanced by reconstituting and reconstructing the lost African culture, including key aspects of Religion, through decolonization.

\section{WAYS IN WHICH DECOLONIZED RELIGIOUS EDUCATION CONTRIBUTE TO SUSTAINABLE DEVELOPMENT IN AFRICA}

\section{Religion and Moral Values, a Prerequisite for Development}

Moral values are religious ideas that provide direction and guidance on how to live and relate to each other (Mbiti (1991) as cited in Alolo, (2007); Omoseghbon (2010) in Agbiji \& Swart, 2015). They are rules of conduct within a social group a frame of reference for critical examination of existing social value systems (Agbiji \& Swart, 2015), thus, the key to future development in Africa. Moral values are important because they help determine social, economic and political stability, thus facilitates sustainable development in Africa (Agbiji \& Swart, 2015; Ekeopara \& Ekpenyong, 2016).

According to Mbiti 1991 in Alolo (2007), Africans live in a rich religious environment that informs them of philosophical understanding of their myths, customs, traditions, beliefs, morals values, actions and social relationships. African Religious traditions cherish such moral values as truth, respect, justice, the sanctity of human life, equality and dignity, love, decency, character, integrity, good and evil (Mbiti 1991 in Alolo, 2007; Agbiji \& Swart, 2015), which are catalyst to fast tracking 
people's characters, behaviours and attitudes (Ekeopara \& Ekpenyong, 2016). To Agbiji and Swart (2015), African Traditional Religion remains a potent force on a sub-conscious level and continues to influence values, identity and outlook of Africans, the key aspect of development.

As a key source and promoter of moral values, Religious Education mould the religious and moral character of students (Ene \& Barna, 2014; IkechiEkpendu, Audu \& Ekpendu, 2016; Ozioma, 2017). Religious Education makes students moral beings, integrating them into the nation as good, sound and effective citizens. Thus, Religious Education provides moral, psychological, social and spiritual infrastructures in which the superstructure of social, economic development of any nation is based (Ilechukwu, 2014). Religion shows students the importance of accountability, honesty, integrity, transparency, right attitudes to wealth, dignity of labour, forgiveness, discipline, loyalty, individual responsibility and patriotism (Ogbonnaya, 2012; Ilechukwu, 2014) which are crucial for Africa's economic development and formation of democratic political systems (Agbiji \& Swart, 2015). Such teachings can go a long way in helping deal with issues of corruption, consequently lead to wealth creation, while improving the social and economic fabrics of African society.

Social harmony and morality can be achieved through the application and enforcement of taboos which are inextricable attributes of African religion. For instance, taboos regulate people's behaviour, by ensuring sanity for instance, it is taboo to steal from public treasury or communal properties (AwuahNyamekye, 2012). The phenomenon of corruption has become pervasive and continues to weaken the moral fabric of the African countries, in particular Kenya, Nigeria, Ivory Coast, South Africa and Zimbabwe. For instance, Kenya loses 4 billion USD (25 to 30 percent of the total budget through corruption (GITZ 2015 in Ozioma, 2017) every year which is a big threat to social, economic and political development. In 2020, Kenya Medical Supplies Authority (KEMSA) is on the spot because of mishandling $\$ 7.8 \mathrm{~m}$ meant to purchase Protective Personal Equipment (PPE) for healthcare workers in hospitals during the COVID-19 Pandemic. I concur with Ozioma (2017) sentiments that the absence of moral values is to a large extent responsible for the challenges facing the African continent which is likely to undermine sustainable development.

\section{Religious Education, Conflict Resolution and Peace Building}

Sulaiman \& Yemisi (2012), Ekeopara \& Ekpenyong (2016) and Tenaw (2018) argue that Religion is important because it advocates for peaceful coexistence, thus, it is an integral factor in peacebuilding and reconciliation. Since African Traditional Religion advocates for peace, it is can be instrumental in building a peaceful African continent (Kagema, 2015). What this means is that there is a need for people of diverse cultures, religions, ethnic groups, traditions and languages to be together, communicate and foster a common front while maintaining their ethnic identities (Katola, 2014; Ekeopara \& Ekpenyong, 2016). Such an arrangement is likely to lead to peaceful coexistence, a key aspect in promoting sustainable development (Ogbonnaya, 2012; Katola, 2014; Ekeopara \& Ekpenyong, 2016).

Africans rely on Religion to promote justice and reconciliation. Ethical values and dogmas of peace, love, kindness, tolerance, respect, fairness, justice, forgiveness and consideration for others (Sulaiman \& Yemisi, 2012; Ogbonnaya, 2012) enhance the promotion and dissemination of peace messages among conflict and war-torn communities. For instance, inter-tribal conflicts in Kenya are usually characterised by cattle rustling driven by scarce water and pastoral land, especially among Pokot, Turkana and Marakwet (Smock, 2006 in Mafungulwa, 2014; Tenaw, 2018). Other conflicts have been witnessed in Sudan, Mozambique, South Africa and Somalia to mention but a few. Respect which gives rise to tolerance, cooperation and peace among the neighbouring communities is emphasised in African Traditional Religion (Katola, 2014), which to some extent can be used to resolve conflicts and wars. Further, it is important to note that there are established mechanisms, ethical codes and sanctions which can be used to restore social harmony and peace in the African traditional society, leading to conflict resolution (Katola, 2014).

Institutions of ancestorship served as conduits of peace and harmony; elders who were ethical 
professionals taught guidance and counselling, while religious teachers restored peace through prayers, sacrifices and offerings (Kasomo, 2010). Kasomo (2010) further noted that covenants (marriage, buying land) served as preventive measures against possible threats of peace and tranquillity. In addition, taboos were used to enhance peace, harmony, sanity, stability and development, since breaking certain taboo is considered a sin (Awuah-Nyamekye, 2012). It is clear from Kasomo's (2010) sentiments that Africans should not disregard beliefs and practices that are instrumental in promoting peace among the diverse groups since the focus of African Religion is life.

Today Religious Education and in particular African Traditional Religion has significantly created an enabling environment and stability. According to Ilechukwu (2014), the peaceful atmosphere help people develop their full potential leading to the generation of wealth. Mafungulwa (2014) noted that Religious Education promotes human capital required for industrial development, which makes Africans acquire relevant skills and knowledge, thus, increase productivity and stimulates development. Thus, a peaceful state is a precondition and conducive space for prosperity, growth and sustainable development (Ellis \& Harr, 2004; Mafungulwa, 2014). The contemporary African society has continued to overlook principles that enhance peaceful coexistence and religious mechanisms used in resolving conflicts giving priority to mechanisms that have failed (Kasomo, 2010). There is a need to modify African traditional ways to suit the prevailing circumstances in contemporary society while being ecumenical to embrace all denominations since each has something positive to offer to Africans.

\section{Religious Education, Management and Conservation of Environment}

Studies done by Ellis and Harr (2004); Kideghesho (2009); Awuah-Nyamokye (2012); Ekeopara \& Ekpenyong (2016); Ming'ate \& Karigu (2018) shows that Traditional African religious networks (rather than Christian or Muslims) continue to play a substantial role in the management and conservation of resources in Africa. Although most of the Africans have adopted Christianity and other foreign religions, a majority still believe in the God of their forefathers who live in sacred places like forests and hills (Ming'ate \& Karigu, 2018). According to Ming'ate \& Karigu (2018), most of these places have been reserved for worship, prayer and offering of sacrifices to the ancestral spirits.

Kideghesho (2009) who did a study in Tanzania reported that traditional cultural practices, previously regarded as inferior or incompetent have promising potential and complement other existing conservation strategies to enhance sustainable use of resources and conservation. This is likely to lead to the achievement of ecological and social sustainability. Practices like taboos, beliefs, totems and other conservation related regulations affiliated with localities have effectively been used to protect important ecological and economic wild flora and fauna species.

Kideghesho (2009) and Awuah-Nyamokye (2012) are in agreement that taboos derived from religious and established traditional beliefs and social customs, are used by kings, priests and elders as moral or cautionary restrictions on certain actions. Specific taboos protect flora and fauna by regulating and prohibiting harvesting, detrimental use and consumption. Habitat taboos control access and use of resources in a particular area, for instance, sacred habitats, thus checking anthropogenic interference detrimental to flora, fauna and their habitats. Although there is a lack of formal legal backing, taboos and regulations are very effective in regulating human behaviour and ensuring compliance to societal values, thus enhances conservation. The reason behind successful conservation is the belief that non-compliance with regulations or taboos governing sacred species or sites (groves, forests, hills or streams and other water bodies) amounts to catastrophic events such as disease outbreaks, death, severe drought, pests or loss of assets.

Further, penalties for failure to comply with regulations governing sacred sites apply to all people, regardless of one's ideological belief. Traditional societies have set aside species, sites and protected them from destruction through taboos and cultural beliefs (Kideghesho, 2009). Kideghesho (2009) and Awuah-Nyamokye (2012) specifically noted that sacred groves and forests (homes of 
totemic plants and animals) are protected, conserved and maintained through a combination of taboos, prohibitions, beliefs and restrictions. Such sites and species are key to biodiversity conservation. Conservationists see the potential of sacred sites as an opportunity for promoting the conservation of rare and endangered species (Kideghesho, 2009; Awuah-Nyamokye, 2012), likely to promote cultural tourism. Cultural tourism entails showing cases for cultural identities in terms of education, local customs, arts, craft, traditional dancers, music, food and drinks (AwuahNyamokye, 2012).

Further, African traditional culture is an aspect of tourism because its promotion, preservation and presentation are designed to attract tourists. African Traditional Religion has great potential in unlocking the growth and developmental aspirations of Africa. It helps to promote culture and the environment and is an important tool for economic and social development. Culture industry, tourism can create employment, leading to sustainable development (Ekeopara \& Ekpenyong, 2016).

Many African societies consider species, like sacred totems to be of religious and spiritual significance while playing a symbolic role in different clans and tribes. To underscore the importance of totemic species, some families or clans are named after the species. The totemic status assigned to different species has a significant role in their survival since they are less subject to human impact, and are protected through taboos and beliefs that prohibit harvesting, hunting, killing, consumption or destruction of their habitats. Killing, destroying or consuming totemic species may lead to punishment by clan or tribal elders, and by doing so they are able to conserve the ecological system (Kideghesho, 2009). According to Kideghesho (2009) and Awuah-Nyamokye (2012) environmental consciousness was part and parcel of traditional African life and was used to place strict measures to ensure appropriate environmental conservation.

It was a sin for people to cultivate near watersheds or the source of a river (Ekeopara \& Ekpenyong, 2016). Water tower, leads to provision of water, source of life (drinking, farming, animals etc) while enhancing food security, an essential element in sustainable development. Traditional religious belief systems and cultural practices encourage the conservation of natural resources and forests, especially where plants, animals, rocks, water and other non-living things are respected as part of nature with no separation between secular and sacred (Ekeopara \& Ekpenyong, 2016). Traditional ethical principles on environmental conservation and protection discourage desertification and deforestation. Water conservation and preservation are achieved through the use of totems, taboos, other cultural and religious rites, which shows African ways of respecting their gods, ancestors and spirits.

Results of a study done among the Tugen, Njemp and Pokot communities in Kenya, Ming'ate \& Karigu (2018) reveal that Religion, God and sacred places of worship enhance the conservation of the ecosystem. The sacred hills and forests are reserved for native herbs usually used for medicinal, social and religious purposes. This common belief provides intrinsic values that guide and regulate utilisation, conservation and management of resources. For instance, during the initiation and marriage rites the young Tugen, Njemp and Pokot are trained by elders to be responsible adults and members of the community. Since initiation rites are performed near the rivers or in the forests, this leads to the management and conservation of the ecosystem. This further leads to the preservation of communities' cultural heritage and wealth.

According to Ellis and Harr (2004), the relationship between people and the land they cultivate or live on is usually governed by spirits. This conviction has been turned into positive results leading to conservation of ecosystem and environment. For instance, the work of the Association of Zimbabwean Traditional Ecologists (AZTREC) associated with traditionalist of land and Nobel Laureate Wangari Maathai (Kenya) have been responsible for major campaigns of large-scale tree planting and conservation projects (Ellis \& Harr, 2004).

\section{RECOMMENDATIONS}

\section{To what extent has the Religious Education Curriculum in Kenya been Decolonized?}

In the current Competency Based Curriculum (CBC), RE activities mainly covers Christianity, 
Hinduism and Islamic religions, with minimal integration of key dimensions of African Traditional Religion. In the 8.4.4 system of education, African Traditional Religion in Christian Religious syllabus is only covered in Form one under: 'Selected Aspects in African Religious Heritage and African moral and cultural values'. It is important to note that African Traditional Religion in the 8.4.4 Christian Religious Education syllabus and Competency Based Curriculum is yet to be decolonized. Similarly, Mtombana and Mokotsa (2018) reported that the Religious Education curriculum in Lesotho continues to promote Christianity over African Traditional Religion, which means the curriculum is largely influenced by teachings of mainstream Christian beliefs and traditions. Yet, according to Agbiji \& Swart (2015); Kagema (2015) African Traditional Religion can be integrated with other religious systems, beliefs and practices for purposes of mutual coexistence. Since African Traditional Religion is a positive force necessary for the moral, socio-political and economic transformation of African societies (Agbiji \& Swart, 2015), there is a need to ensure more of its coverage in the Religious Education curriculum.

\section{Multi-Faith Religious Education Curriculum and Sustainable Development}

A number of scholars, Matembo (2009); Gearon (2014); Ntombana \& Mokotso (2018) have discussed ways in which multi-faith Religious Education (inclusive aspects of Christianity, African Traditional Religion, Buddhism, Hinduism, Islam and Sikhism) can enhance social, economic, cultural and political development in Africa.

\section{Multi-Faith Religious Education for Religious Tolerance and Peace Building}

Promoting inter-religious dialogue, multi-faith pedagogy and education is likely to reduce religious conflicts since such a pedagogical approach fosters a better understanding of tolerance in a multireligious dispensation (Matembo, 2009; Ogbonnaya, 2012), and in a world where pluralistic and heterogeneity rather than homogeneity is the acceptable reality (Matembo, 2009). Interfaith Religious Education curriculum can positively contribute to religious tolerance which in turn promotes peace building (Brahm, 2005 in Mafungulwa, 2014). This is because a multi-faith curriculum exposes students to other religious strands, making them globally conscious citizens, and in turn, they are more likely to tolerate religious diversity (Mtombana \& Mokotsa, 2018). Since multi-faith Religious Education makes learners fully aware of different beliefs, Gearon (2014) and Partington (2017) claim that school curricula should avoid imposing a particular or single faith norm and religious traditions among students from different faiths, denominations, or those without religion. Further, Partington (2017) noted that if Religious Education has to make learners critical thinkers, they should be given an opportunity to be aware and respect other people's beliefs and faiths (Ozima, 2017). Emphasis on religious tolerance may lead to peaceful co-existence, create conducive religious environment, likely to facilitate sustainable development in Africa.

\section{Multi-Faith Religious Education and National Unity}

Religious pluralism represents a positive attitude toward the co-existence and cohesion of diverse religions in the society (Riis, 2011). For instance, about $\quad 70 \%$ of Kenyans are Christians (38\% Protestant, 28\% Catholic); 25\% are adherents of African indigenous religions; $6 \%$ are Muslim. Among the Asian community, there are Hindus, Sikhs, Parsees and Bahais. Kenya is a multi-ethnic country with over 40 ethnic groups (Partington, 2017). Partington (2017) found that Religious Education students who are graduates of the 8.4.4 system of education have little appreciation of other belief systems within their communities, which could affect social cohesion. The inclusion of religious multiplicity in the school curricula is more likely to foster understanding in a multi-religious dispensation leading to national unity (Matembo, 2009), which is key to the achievement of sustainable development in Africa.

\section{Decolonized Religious Education and Pedagogical Approaches}

The use of decolonized pedagogical approaches allows students to interpret and share Religious Education content based on their real-life experiences, cultural norms, personal belief 
systems, preferences and backgrounds. Learner centred curriculum ensures that students are not confined to examinations but that they are able to apply the knowledge acquired in their day-to-day life (Musitha \& Mafukata, 2018). Change in pedagogical approach (liberation/dialogical approach) is necessary since Kenya's Competency Based Curriculum aims at making learners acquire relevant skills, attitudes, values and patriotism. This requires adequate in-service courses and close follow-up of Religious Education teachers if there has to be effective implementation of appropriate pedagogical practices and approaches.

\section{CONCLUSION}

To be able to realise a reconstructed society through Religious Education, concerted efforts by all stakeholders are inevitable (Igwe, Rufai \& Olufemilgwe, 2013). African governments should promote the teaching of Religious Education, as they have done with the sciences and technological subjects; in order to produce a morally upright society ready for technological advancement and industrialisation. This is clearly stipulated in Kenya's Vision 2030 and 2017-2022 Jubilee Government's Manifesto (Big Four Agenda). This is likely to facilitate the achievement of Post-2015 Sustainable Development Goals.

\section{ACKNOWLEDGEMENT}

The paper was presented on March $14^{\text {th }} 2019$ during the Academic Symposium on Decolonising Knowledge and African Development, held at the College of Education and External Studies, University of Nairobi, Kenya.

\section{REFERENCES}

Agbiji, O.M. \& Swart, I. (2015). Religion and social transformation in Africa: A critical and appreciative perspective. Scriptura, 114 (2015), $1-20$.

Alolo, N.A. (2007). African Traditional Religion and Concepts of Development: A Background Paper. Working Paper 17-2007. Birmingham, UK: African Development Bank \& University of Birmingham.
Amanze, J. N. (2012). The voicelessness of theology and religious studies in contemporary Africa: Who is to blame and what has to be done? Setting a new agenda. Missionalia: Southern African Journal of Mission Studies, 40(3), 189-204.

Awuah-Nyamekye, S. (2012). Religion and development: African Traditional Religion's perspective. Religious Studies and Theology, 31(1), 75-90.

Byrne, G. (2014). Why religious education has an important role to play in our society. The Irish Times, 3-7.

Ekeopara, C. A. \& Ekpenyong, O. E. (2016). African traditional religion and national development in Nigeria. Research on Humanifies and Social Sciences, 6(22), 19-28.

Ellis, H. \& Harr, G. T. (2004). Religion and Development in Africa, In Ellis, H. \& Harr, G. T. (2004) (Eds). Worlds of Power: Religious Thought and Political Practice in Africa, (2nd ed, pp.115-120). London, UK, C. Hurst and Co.

Ene, I. \& Barna, I. (2015). Religious education and teachers' role in students' formation towards social integration. Procedia-Social and Behavioural Sciences, 180, 30-35.

Gearon, L. (2014). The paradigms of contemporary religious education. Journal for the Study of Religion, 27(1), 52-81.

Igwe, R. O. Rufai, S. A. \& Olufemi, A. G. (2013). Social reconstruction through Religious Education: A survey on Nigeria. Humanity \& Social Sciences Journal, 8(1), 10-18.

Ikechi-Ekpendu, C. Audu, S. D. \& Ekpendu, I. C. (2016). An evaluation of the role of religion in the development of Nigeria. Developing Country Studies, 6(10), 82-87.

Ilechukwu, L. C. (2014). The place of Religious studies in human development, entrepreneurship and wealth creation among students in tertiary institutions in Nigeria. Research on Humanities and Social Sciences, 4 (24), 78-86. 
Kagema, D. K. (2015). The role of the African Traditional Religion in the promotion of justice, reconciliation and peace in Africa in the twentyfirst century: A Kenyan experience. International Journal of African and Asian Studies, 15, 1-9

Kasomo, D. (2010). The position of African Traditional Religion in conflict prevention. International Journal of Sociology and Anthropology, 2 (2), 023-028.

Katola, M.T. (2014). Incorporating of traditional African cultural values in the formal education system for development, peace building and good governance. European Journal of Research in Social Sciences, 2(3), 2056-5429.

Kideghesho, J. R. (2009). The potentials of Traditional African cultural practices in mitigating over exploitation of wildlife species and habitat loss: Experiences of Tanzania. International Journal of Biodiversity Science and Management, 5 (2), 83-94.

Mafungulwa, M. A. (2014). The contribution of quality Religious Education to development of education in Africa. Mediterranean Journal of Social Sciences, 5(23), 102-110.

Matembo, Y. H. (2009). Religious Education in the context of Sub-Saharan Africa: The Malawian example. British Journal of Religious Education, 31 (1), 41-51.

Mbiti, J. S. (1999). African Religions and Philosophy, Heinman, Oxford Press.

Minga'te, M. L. F. \& Karigu, M. (2018). Uses of community cultural practices and beliefs in the conservation of Lake Baringo ecosystem in Kenya. International Journal of Natural Resource Ecology and Management, 3 (3), 3238.

Msila, V. (2017). Decolonising Knowledge for Africa's Renewal. Examining African Perspectives and Philosophies, South Africa, KR Publishers.

Musitha, M. E., \& Mafukata, M. A. (2018). Crisis of decolonising education: Curriculum implementation in Limpopo Province of South
Africa. Africa's Public Service Delivery and Performance Review, 6(1), 1-8.

Naaman, K. R. (2015). African Traditional Religion a sub-structure for sustainable development in Africa: A Kenyan perspective. International Journal of Humanities and Social Sciences 2 (3), 2222-2863.

Ntombana, L., \& Mokotso, R. (2018). God is not Christian": A case for decolonising of Religious Education for inclusive Education in Lesotho schools,". Pharos Journal of Theology, 99, 1-13.

Ogbonnaya, J. (2012). Religion and sustainable development in Africa: The case of Nigeria, International Journal of African Catholicism, $3(2), 1-22$.

Ozioma, N. G. (2017). Religious Education as developmental tool in the $21^{\text {st }}$ Century Africa. IOSR Journal of Humanities and Social Science (IOSR-JHSS), 22(1), 63-67.

Partington, S.O. (2017). Religious Education in Kenyan schools-Profoundly unethical; Voices Awaaz Magazine, 3(3).

Riis, O. (2011). Rejection of Religious pluralismThe Danish case. Nordic Journal of Religion and Society, 24 (1), 19-36.

Rodney, W. (2012). How Europe Underdeveloped Africa. Dakar, Senegal: Pambazuka.

Savo, H. (2018). Decolonising knowledge in South Africa: Dismantling the 'Pedagogy of big lies'. Ufahamu: A Journal of African Studies, 40(2), 47-65.

Sulaiman, K. \& Yemisi, O. M. (2012). The role of Religious Education to peace, security and sustainable development in Nigeria. IOSR Journal of Humanities and Social Science, 3(6) 1-5.

Tenaw, A. (2018). The role of Religious institutions for conflict management: Experience of National Council of Churches of Kenya. International Journal of Humanities, Art and Social Studies (IJHAS), 3 (1). 
Tshimpaka, L. M. (2018). Curbing Inequality through decolonising knowledge production in Higher Education in South Africa. Australasian Review of African Studies, 39 (1), 53-81.

Unterhalter, E. Allais, S. Howell, C. Adu-Yeboah, C. Fongwa, S. Ibrahim, J. McCowan, T. Molebatsi, P. Morley, L. Ndaba, M. Ngcwangu, S. Oanda, I. Oketch, M. Posholi, L. \& Selepe, C. (2019). Higher Education, Inequalities and the Public Good: Perspectives from Four African Countries. Research Report. CODESRIA, University of Witwatersrand, National Research Fund, Newton Fund, Economic and Social Research Council.

Wa Thiong'o, N. (1981). Decolonising the Mind: The Politics of Language in African Literature, Nairobi, KE: East African Educational Publishers Ltd. 